\title{
Demolition Waste Management in Spanish Legislation
}

\author{
Madelyn Marrero*, Jaime Solis-Guzman, Borja Molero Alonso, Manuel Osuna-Rodriguez and \\ Antonio Ramirez-de-Arellano
}

Ave. Reina Mercedes 4-A, 41012 Seville, Spain

\begin{abstract}
In 2008, a legal frame was established in Spain for construction and demolition waste management. The new control model, called the Alcores model, presents a waste management closed loop and was previously tested in Seville in order to demonstrate its viability. In current demolition projects, specific barriers arise which limit the frame implementation. Until recently, demolition was considered a low technical process. The contractor's main goals were quick demolition and disposal of the debris, usually uncontrolled, into landfills. No special measures for separating different material types were taken due to their incompatibility with the work time-span required. The present work establishes a simplified procedure in order to fulfill Spain's legal frame. This procedure determines the management of demolition waste quantities and costs following the Andalusia Construction Information Classification System. The procedure also generates the demolition waste management plan, which includes: previous work, waste quantification, hazardous waste inventory, waste prevention action plans, reuse, valorisation and disposal plan, separation plan, technical drawings, technical instructions, and budget. Finally, as an example, the procedure is applied to a school demolition project.
\end{abstract}

Keywords: Construction and demolition waste, demolition project, waste cost, waste quantification, waste legislation.

\section{INTRODUCTION}

In the years immediately prior to the current Spanish economic crisis, the construction sector enjoyed a level of high activity, and constituted a key to Spain's economic growth. This situation caused vast waste generation due to the construction and demolition of buildings and infrastructure, including that derived from small renovations of homes and shops [1]. All this waste is part of a category called construction and demolition waste, otherwise known as $C \& D$ waste.

The environmental problem posed by $\mathrm{C} \& \mathrm{D}$ waste is derived not only from the increased volume, but also from its treatment. Some of the environmental impacts are: contamination of soil and water resources by uncontrolled landfills, deterioration of the landscape, and above all, waste elimination without recycling or re-using the material [2].

The tendency in the field of construction is to consider C\&D waste as inert waste to be deposited in landfills, and, in some cases, in uncontrolled dumps. C\&D waste management requires a tendency change towards prevention of the generation of waste and, failing this, towards waste recycling and re-use and/or energy recovery.

No legal framework in Spain was previously in existence to regulate actions in a sustainable manner. In this context, the National Plan of Construction and Demolition Waste [3] developed the Spanish Royal Decree 105/2008 (RD $105 / 2008$ ) which is a specific legislation at state level for C\&D waste production and management [4]. After an

\footnotetext{
*Address correspondence to this author at the Ave. Reina Mercedes 4-A, 41012 Seville, Spain; Tel: (34) 954-556-662; Fax; (34) 954-556-691; E-mail: madelyn@us.es
}

adaptation period, that legislation is now compulsory on all C\&D waste generated. The legislation objectives are summarized in a waste hierarchy, which runs from the most to the least efficient measure: prevention, reuse, recycling, energy recovery and adequate waste disposal.

In order to attain these new objectives, three key areas have been identified: a good waste quantity estimate, waste separation at origin, and differentiated management definitions for each waste type. This is similar to the strategies of other countries, for example, the Code for Sustainable Homes in United Kingdom [5] has identified the following strategies to meet the objectives,

- storage space for recyclable materials during construction,

- workers on site must become directly involved in the process though separation/sorting of the waste into clearly labelled skips with good access for collectors,

- all contractors must take part in a waste reduction strategy.

The first point, storage space, can only be managed properly if a good prediction of the amount and kind of waste is determined from the demolition project definition. The second point, workers involvement, can be achieved by assigning specific responsibilities to workers and coordinators. The last point, the waste reduction strategy by contractors, is an interesting initiative and its inclusion in the project during development is vital. In this scheme all contractors must implement a strict waste minimisation strategy, but it is not enough to simply define a strategy in order to achieve waste reduction. A clear plan with detailed objectives, tactics and strategies is needed in order to meet such goal. 
In a similar way, other researchers have analyzed and evaluated the application of the environmental management system (EMS) ISO Standards 14001 to construction sites in the Autonomous Community of Madrid [6]. Their results suggest that EMS on worksites helps promote the fulfillment of the relevant current legislation and the appropriate management of solid, inert and hazardous waste. For example, with regard to reuse, $11.8 \%$ of inert waste from EMS sites is reused on another site, as against $5.8 \%$ on nonEMS-sites.

In the particular case of a demolition project, specific management problems arise. First, demolition, until recently, was considered a low technical process. The contractors' main goals were quick demolition and disposal of the debris, usually uncontrolled, into landfills. No special measures for separating different material types were taken due to their incompatibility with the work time-span established.

Second, waste classification in demolition is a more complicated process than that which takes place in new construction and renovation. Optimum waste handling and recycling depend on separating in situ and coordinating the demolition processes properly. For example, a selective demolition implies that waste separation is carried out, both before and during demolition, in order to prevent material mixing and contamination of recyclable material such as wood, paper, cardboard and plastic. Naturally, this makes the demolition processes more expensive than traditional methods. Nevertheless, the economic savings derived from selecting the debris during the demolition process is far greater as this process implies a higher quality in the recycled aggregate which means there is no need to perform a further selection at the recycling plant [7]. For example, II C\&DW Management Plan [1] rewards those companies which produce a cleaner and more homogeneous product from $\mathrm{C} \& \mathrm{D}$ waste, by reducing the corresponding disposal charges. Therefore, it is necessary to plan and manage demolition work in a completely different way to traditional methods.

As established previously, in current demolition projects, specific barriers arise which limit the framework implementation. The present work establishes a simplified procedure in order to implement the legal frame. The procedure determines the management of demolition waste quantities and costs following the Andalusia Construction Information Classification System [8]. It also generates the demolition waste management plan. Finally, as an example, the procedure is applied to a school demolition project.

\section{SPANISH ROYAL DECREE 105/2008}

Spain has undergone a decade of intense construction activity during which about $60 \%$ of the $C \& D$ waste ended up in illegal dumps without any previous treatment or control, causing soil and aquifer contamination and landscape deterioration [1]. RD 105/2008, enacted on February 1, 2008 [4], regulates the production and management of the C\&D waste from the design stage to construction completion. All the construction participants are required to be involved in the planning, implementation and control of the $C \& D$ waste through prevention, reuse and recycling.
The RD 105/2008 demands the C\&D waste management plan contain:

1) An estimate of the waste amount expected.

2) Action plans for waste prevention.

3) Description of reuse, recovery and/or disposal operations.

4) The waste separation actions at the construction site, in particular, the waste holder separation requirements, as set out in Article 5.5: "The C\&D waste should be separated into the following fractions, when, individually for each of these fractions, the total expected amount exceeds the following: concrete: $80 \mathrm{t}$, bricks, Arabic tiles, ceramics: $40 \mathrm{t}$, metal: $2 \mathrm{t}$, wood: $1 \mathrm{t}$, glass: $1 \mathrm{t}$, plastic: $0.5 \mathrm{t}$, and paper and cardboard: 0.5 t."

5) The site plans for storage, handling, separation and other operations in $\mathrm{C} \& \mathrm{D}$ waste management on the construction site. Subsequently, such plans may be adapted to particular work characteristics; such adaptations need to be previously agreed by the construction technical department on the construction site.

6) The particular technical requirements related to waste storage, handling, and separation, and, where appropriate, other related operations.

7) An estimated management cost that will be part of the project budget in a separate chapter.

8) Where appropriate: an inventory of hazardous waste generated on site; a provision for selective disposal in order to avoid mixing different types of waste with each other, especially with other non-hazardous waste; and a guarantee of delivery by authorized hazardous waste managers.

The concepts contained in the decree were previously tested in the Seville area. A waste management model, known as the Alcores model, was set in place and incorporated in a closed loop system (Fig. (1)), which controls, treats and reuses the waste generated during construction and demolition [9].

The model is based on the principle described in Spain's National Construction and Demolition Waste Plan 20012006 [3], which establishes that any party that produces waste is responsible for its correct disposal. The plan recommends that a monetary deposit should be made to guarantee that producers deal with their own C\&D waste in the most appropriate manner. Consequently, the Alcores model requires a deposit to be paid by the developer of the new construction project or demolition work before any building or demolition permit is awarded by the Town Hall. The amount of that deposit depends on the type of work involved. Once the volume of waste to be generated is estimated, the rates, established by the Los Alcores Community for each Town, are applied [10]. The amount of deposit is the result of applying the corresponding rate to the estimated waste volume. When the work has begun, the developer informs the contractor that the waste generated must be handled by the C\&D waste treatment plant, the concession-holder, designated by the Los Alcores Community. The treatment plants crush the materials and different granular sizes are obtained. The main uses of the recycled material are quarry restoration, rural tracks and land 
refills. The main treatment plants have been located in nonoperational quarries, in order to use the recycled material to restore the plant site.

Once the construction work has been completed, the developer must request a correct management certificate from the treatment plant. It has been demonstrated that the amount of waste delivered by the developer is congruent with the estimate on which the deposit was based. The management model can be summarized as follows: application for a building permit (i), C\&D waste evaluation report (ii), correct $C \& D$ waste management and recycling (iii, iv, v), issuance of correct management certificate (vi), and, finally, the return of the deposit (vii) (Fig. (1)). The most important environmental impact obtained from the Alcores model implementation is the prevention of illegal dumps and the encouragement for developers to reuse and recycle.

The complete demolition processes are summarized in more detail in Fig. (2). First the C\&D waste producer, the project developer, generates a $\mathrm{C} \& \mathrm{D}$ waste management

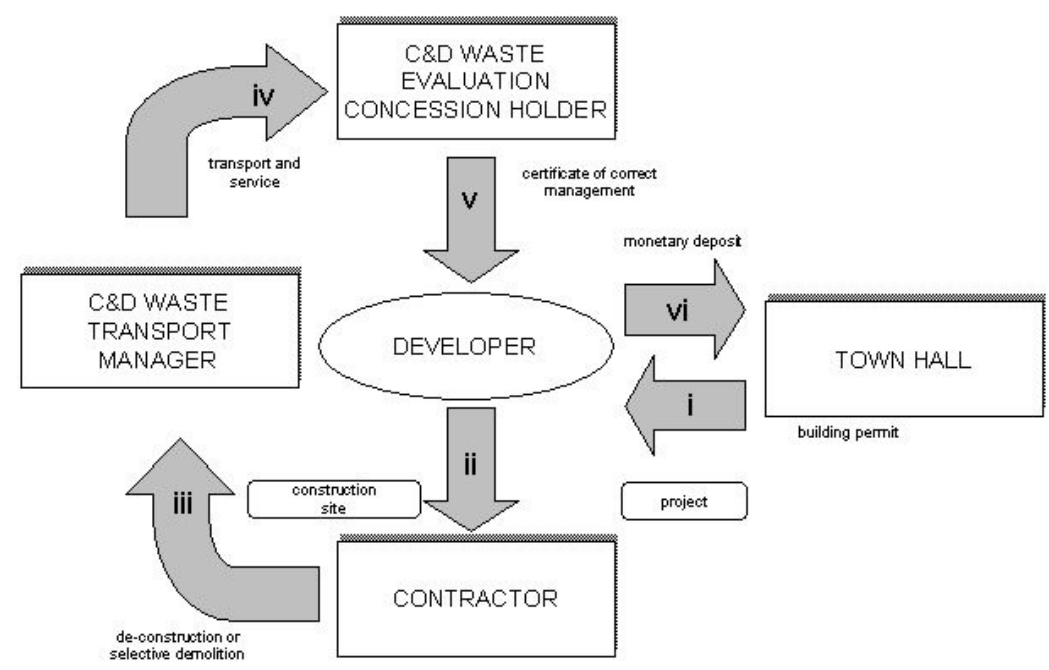

Fig. (1). Alcores C\&D waste management model [9].

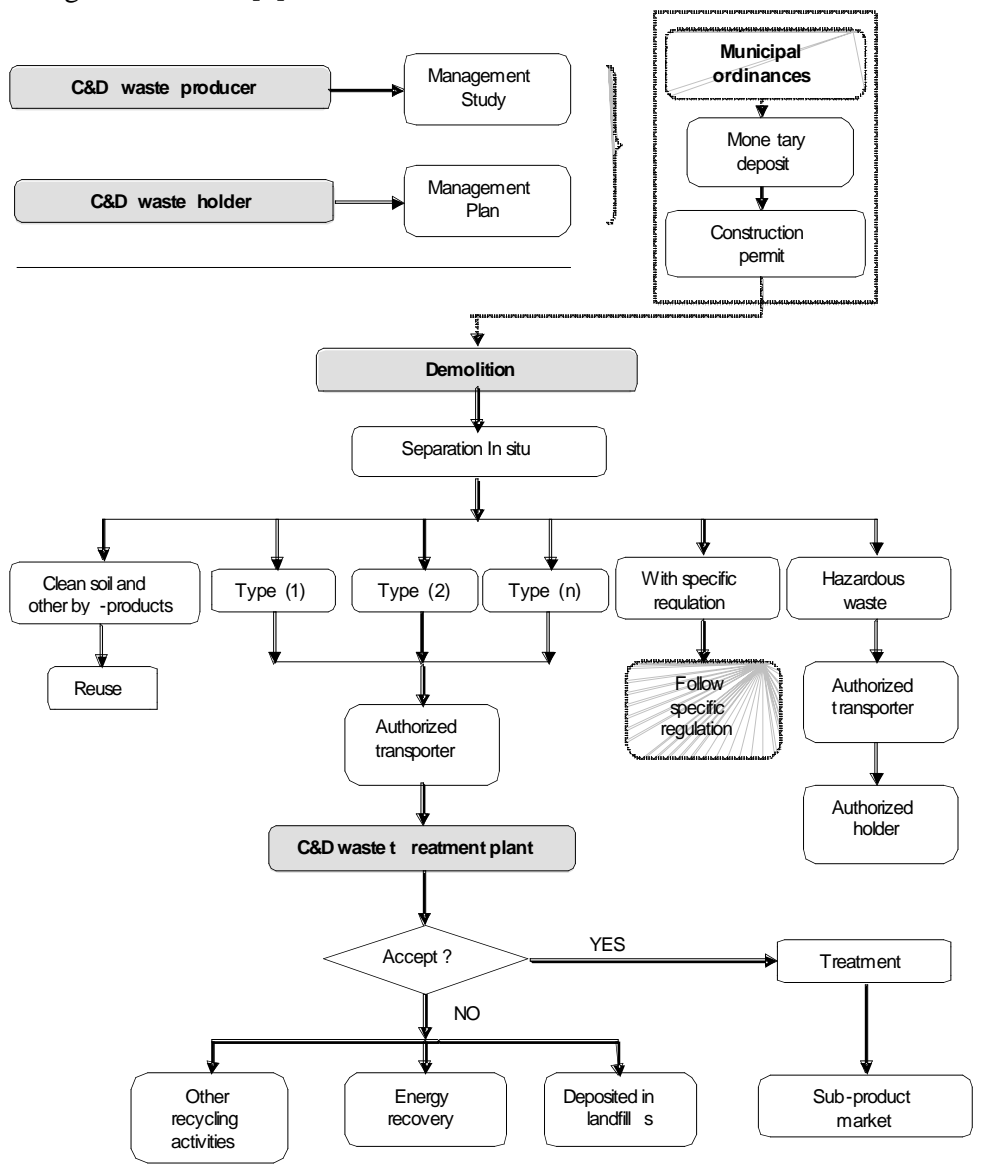

Fig. (2). Demolition waste management processes due to the application of the RD 105/2008 [11]. 
study and plan, then the loop defined in Fig. (1) takes place, which is completed with the material being reused, recycled, in-situ treated and/or deposited in a waste treatment plant or landfill.

\section{WASTE QUANTIFICATION}

A good waste volume prediction not only allows good control of the waste generated during demolition but also good construction site management. The volume determined can be used to define the container sizes and types and the pick-up frequency, both necessary in order to reach the next step: material recycling and/or reuse. A good quantification procedure also allows waste to be properly treated, by preventing mixtures and deterioration [9].

Many models have been established to determine the project waste quantities, such as OEKO Service Luxembourg [12] (SuperDrecksKescht fir Betriber, 2002) which proposes quantification of demolition and construction waste at the worksite, and is able to estimate types and volumes produced. ITEC [13] has also analysed these types of waste and subsequently introduced a computer tool which allows, among other aspects, the quantification and classification of C\&D waste per work package. Another model is SmartWaste [14] which defines quantification and classification according to origin and type, and also generates the waste management plan.

The present authors, together with others, have also developed a quantification model to estimate the type and quantity of waste generated by different construction types such as new buildings, demolition, renovations and alterations [9]. The input parameters in the model are: work type, floor number; foundation type and total built area. Over recent years the model has been tested at the Los Alcores Community treatment plants and has proved to be $95 \%$ accurate in its predictions [9]. The classification code used is the same as that which Spanish quantity surveyors normally employ to obtain the bill of quantities, thereby making the model both easy to understand and to implement [15].

In order to transform the demolition project into waste volumes, the first step is to identify all unitary products that can be generated. In order to establish measurement criteria for the new work units, three transformation coefficients are necessary,

$\mathrm{M}=\mathrm{M}_{\mathrm{o}} \mathrm{C}_{\mathrm{r}} \mathrm{C}_{\mathrm{C}} \mathrm{C}_{\mathrm{T}}$

where: $\mathrm{M}$ is the waste quantity that is obtained from the original material measurement, $\mathrm{M}_{\mathrm{o}} ; \mathrm{C}_{\mathrm{r}}$ is a coefficient that represents the percentage of the original constructive element that becomes waste; $\mathrm{C}_{\mathrm{c}}$ is a coefficient to change the constructive element units into waste element units; and $\mathrm{C}_{\mathrm{T}}$ is a coefficient to transform the measurement criteria from the original constructive element into the measurement criteria of the waste element.

\section{WASTE MANAGEMENT BUDGET}

An important aspect of the decree is to determine the waste management cost. This calls for a work breakdown system (WBS). There are many international WBS which incorporate waste management in their descriptions. For example, Masterformat [16] uses three different main divisions: Procurement and Controlling Requirements, General Requirements, Existing Conditions with subdivision Demolition and Structure Moving. Another WBS, Omniclass [17], has a classification for waste management, within its tables: Cleaning and Waste Management. In a similar way Uniclass [18] has Table J, Work Sections for Buildings, which includes waste management issues. And CESMM [19] has a division Waste on Site, A9 which includes AAdministration and management, A9 Sundry, A9t Articles, materials found on site not connected with the project and A9u Contingencies that allows the description of wasterelated work.

In Andalusia's WBS, the chapter titled Waste Management is formed by sub-chapters: Metals, Asphalt, Concrete-Bricks-Tiles, Insulation Material, Wood-Paper, Soil, and Others. Furthermore, a new family of basic work units is created, see Table 1. The code is completed with 5 numeric characters to define specific units. The classification combines the RD 105/2008 and the European Waste List (EWL) [20].

Table 1. Work Unit Class [15]

\begin{tabular}{|l|l|}
\hline \multicolumn{2}{|l|}{ E. WASTE (Overuse, losses, breakage, etc.) } \\
\hline \hline EA. & Metals and alloys \\
\hline EF. & Asphalt, tar and other tar products \\
\hline EH. & $\begin{array}{l}\text { Concrete, bricks, tiles, ceramic tiles, ceramic material, } \\
\text { gypsum materials }\end{array}$ \\
\hline EI. & Insulation materials \\
\hline EM. & Wood, paper, cardboard, plastics, synthetics and glass \\
\hline ER. & Metallic wreck \\
\hline ET. & Soil \\
\hline EW. & Others \\
\hline
\end{tabular}

Extra characteristics are necessary in order to define cost precisely. The work units within those sub-chapters can be allocated the following conditions: waste put inside containers at the construction site, waste loaded onto trucks at the construction site, waste sent to the recycling centre without unloading, and waste sent to the recycling centre with unloading included.

In order to clearly define the C\&D waste budget, another special cost is incurred due to the fact that waste can be reused on the same construction site, or the waste can be sold for recycling or reuse, thereby generating an income. Therefore the first hypothesis for the C\&D waste cost is that the material recuperated on the construction site belongs to the constructor and its recuperation offsets other costs. This means that negative costs are allowed in the structure in order to represent this type of income.

\section{HAZARDOUS WASTE}

The construction waste is classified in two main groups:

- Non-hazardous: waste that can be reused on the worksite or can be recycled through a crushing process which can 
be inert; waste that does not change in ambient condition; and non-inert waste. See Fig. (3).

- Hazardous: waste that needs special treatment in isolation after which it can be transferred to other industries so that it can be reused or treated by physical, chemical or biological processes that make it less dangerous or safe, or so that it can be dumped in authorised landfills.

Finally, RD 105/2008 requires a hazardous waste inventory from the waste holder during the demolition, rehabilitation, repair or alteration. Selective removal is intended for this kind of waste, in order to prevent their possible mixing either among themselves or with nonhazardous waste on the construction site. The hazardous waste needs to be transported and treated by authorized agents, who are responsible for its proper management. The inventory is to be included in the management study, Article 4:

"Article 4: C\&D waste producer obligations. 1. In addition to the requirements of waste legislation, the producer of construction and demolition waste must meet the following requirements: a) Include in the proposed implementation of the work a management review of construction and demolition waste..."

Some of the potentially hazardous waste that can be found during building demolition, and its corresponding EWL codes are given in Table 2.

In order to manage hazardous waste properly the following recommendations must be followed, in a similar way to those for non-hazardous waste management:

- Estimate and make a prediction of the nature and quantity of the waste to be generated during construction. Based on an early forecast, arrange for the containers whose installation is necessary at the construction site. The containers must be properly labelled for easy identification.
- Instruct the construction staff and establish responsibilities to manage waste and treatment during generation.

- Keep in contact with waste plant managers close to the construction site.

- Transport waste to the chosen deposit site immediately after generation to prevent possible mixing.

- Avoid prolonged waste storage at the construction site.

- For waste storage, provide places with a roof, weatherproof flooring (concrete slabs), anti-spill devices (such as perimeter fabric on collecting devices), and provide for machinery oil and fuel to be collected as hazardous substances and hazardous waste.

- Adopt contingency plans for possible accidental leakages.

\section{CASE STUDY: SCHOOL DEMOLITION PROJECT}

The RD 105/2008 has objectives that can be met by following the strategies established in the Code for Sustainable Homes [5]. The code has very specific and detailed checklists that must be met by contractors in order to fulfil the requirements. First, a Construction Site Waste Management Plan (SWMP) must be generated and implemented. The site plan must include procedures and be committed to sort, reuse and recycle construction waste, either on site or through a licensed external contractor. There are four checklists:

- Checklist 1 , mandatory requirement to confirm that the content of the SWMP is sufficient to meet the mandatory requirements.

- Checklist 2 to confirm the obligation to minimise site waste.

- Checklist $3 \mathrm{a}$ to confirm the obligation to sort and recycle waste.

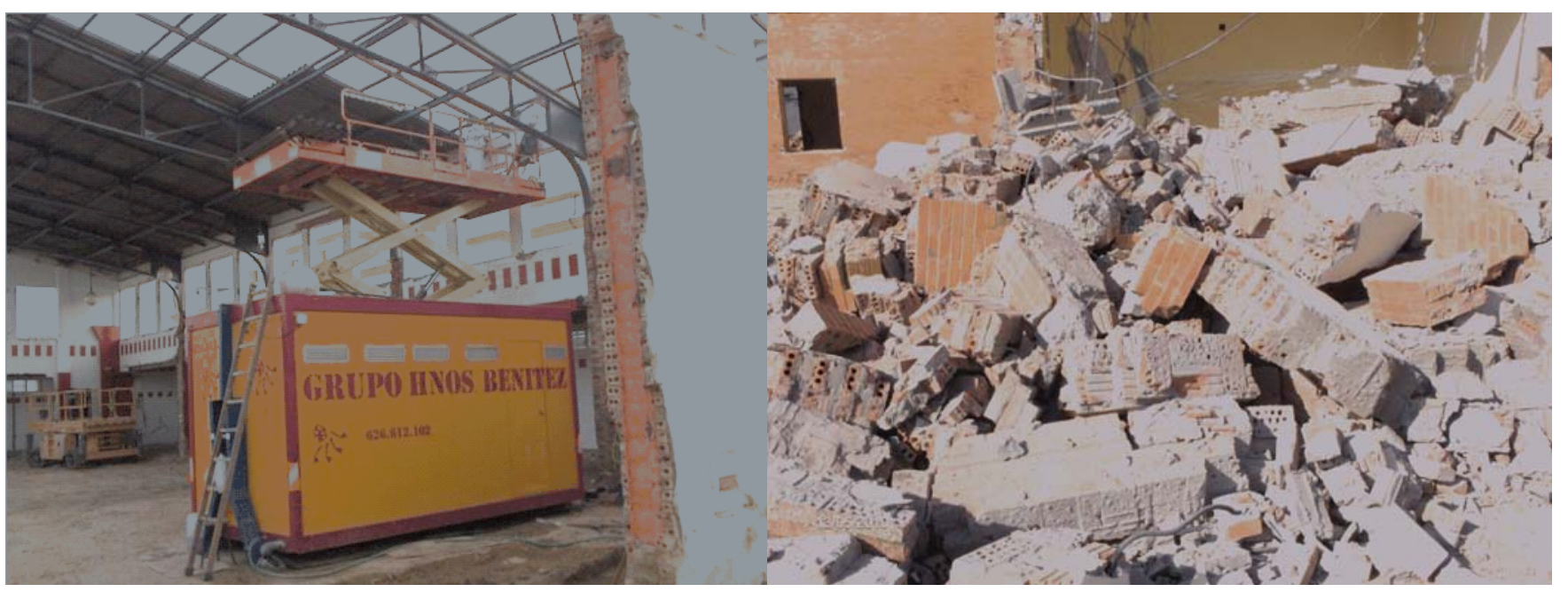

Fig. (3). In the picture on the left, panels containing asbestos are removed as hazardous material by an authorized manager, and on the right, bricks and concrete are treated as non-hazardous and are ready to be crushed and reused. 
Table 2. Most Frequent C\&D Waste in Demolition Projects and its Corresponding EWL Codes

\begin{tabular}{|c|c|}
\hline C\&D Waste: Potentially Hazardous & EWL Code \\
\hline Mixed concrete, bricks, tiles and ceramics with hazardous substances & 170106 \\
\hline Wood, glass and plastic with, or contaminated by, hazardous substances & 170204 \\
\hline Bituminous mixtures containing coal tar & 170301 \\
\hline Metal waste contaminated with dangerous substances & 170409 \\
\hline Insulation materials containing asbestos & 170601 \\
\hline Other insulation materials containing dangerous substances & 170603 \\
\hline Construction materials from contaminated plaster & 170801 \\
\hline Other construction and demolition waste containing hazardous waste & 170903 \\
\hline Land and stones containing dangerous substances & 170503 \\
\hline Contaminated absorbents (wipes ...) & 150202 \\
\hline Oils (mineral-based non-chlorinated engine oil) & 130205 \\
\hline Fluorescent tubes & 200121 \\
\hline Alkaline and saline batteries & 160604 \\
\hline Empty metal or plastic containers contaminated & 150110 \\
\hline Remaining paint or varnish & 080111 \\
\hline Remaining non-halogenated solvents & 140603 \\
\hline Remaining concrete release & 070701 \\
\hline C\&D waste mixed of different codes 170901,02 and 03 & 170904 \\
\hline
\end{tabular}

- $\quad$ Checklist $3 b$ to identify the waste categories to be sorted and recycled.

Each list corresponds to specific criteria to be followed by the project and requires physical evidence to demonstrate how the criteria will be met. This evidence is accomplished through written contracts with enterprises authorized in material recycling and waste management. It is also necessary to establish a person responsible at the construction site for each item on the checklists.

The Construction and Demolition Waste Management Plan in compliance with RD 105/2008, Article 5, describes the duties of the construction and demolition waste holder. The plan shows how to carry out its obligations in relation to the waste to be produced on site, in particular those contained in Articles 4 and 5. This plan, once approved by the construction site technical management and accepted by the promoter, will become part of the contract documents. The main parts of the C\&D waste management plan are: waste quantification, hazardous waste inventory, waste prevention action plans, reuse, valorisation and disposal plan, separation plan, technical drawings, technical instructions, and budget.

In order to clarify the model described in the previous sections, a C\&D waste management plan for a school demolition project is described in this section. Demolition, reuse, and recycling, take place in the project.

\section{Project Characteristics}

The project characteristics identified are the following: the property is of $7186 \mathrm{~m}^{2}$ of which $1997 \mathrm{~m}^{2}$ is constructed; the construction is formed by two two-storey buildings, and two sports tracks, of 1057 and $801 \mathrm{~m}^{2}$. The demolition project includes the total building demolition where the floors are of a height of $6 \mathrm{~m}$ each. The interior partitions of the building are $5.7 \mathrm{~m}$ in height. The foundation consists of a concrete slab, $15 \mathrm{~cm}$ thick, on top of concrete trenches of 1000x $1000 \mathrm{~mm}$ sections. The structure is made of solid brick walls around the perimeter, and $30 \mathrm{~cm}$-thick concrete laid in one direction. The roof structure is comprised of rolled steel trusses with a rectangular cross-section $\left(50 \mathrm{Kg} / \mathrm{m}^{2}\right.$ surface covered) and the roof is covered by omega profile plates, with a $12 \%$ slope. The interior doors are made out of wood and the exterior doors are aluminium. The interior lighting of the building is provided by fluorescent tube skylights $(2.5$ tubes $/ \mathrm{m}^{2}$ ). The air-conditioning system is composed of 2 air conditioners, which contain $2.60 \mathrm{~kg}$ of R22. The sport tracks are $15 \mathrm{~cm}$-thick concrete. The fence consists of brick walls and metallic grids of $1.5 \mathrm{~m}$ height $\left(3 \mathrm{~kg} / \mathrm{m}^{2}\right)$.

After the waste sources have been identified the next step is to define their destination: reuse, recycle or deposit. The material to be reused is the unwanted soil and crushed tiles and bricks. The unwanted soil excavated is reused as land refill in an adjacent construction site, $4 \mathrm{~km}$ away. $80 \%$ of the tiles and concrete waste is to be reused in the sub-base of a 
new building foundation since the same company that is carrying out the demolition is also building the new foundation. The remaining $20 \%$ tile and brick waste is taken to the nearest $C \& D$ waste treatment plant located $13 \mathrm{~km}$ away.

The materials to be recycled are aluminium, glass, iron and steel. The metallic waste is sent to a metal recycling plant located at a distance of $15 \mathrm{~km}$ and the glass waste is sent to a glass recycling plant situated $14 \mathrm{~km}$ away.

Finally, hazardous waste, in the form of elements containing PCB and HCFC, is collected from the construction site by authorized handlers. The remaining demolition waste is to be sent to a C\&D authorized treatment plant which is located $15 \mathrm{~km}$ away.

\section{Previous Actions}

Even though RD 105/2008 includes no previous action description within the Waste Management Plan, from experience the following criteria must be met in order to perform the demolition properly:

1. Identification of all waste that can cause delays in the demolition process. For example, removal of hazardous waste such as asbestos, PCB, lead pipes, hydrocarbons, paints, adhesives, and treated wood.

2. Forecast the necessary waste management space on the construction site in order to meet Article 5.5 of the decree.

3. Analyze waste management costs and the possible waste destinations.
4. Locate on-site waste treatment facilities for an appropriate selective demolition.

These actions greatly improve the waste management plan implementation.

\section{Waste Quantification}

Tables 3 and $\mathbf{4}$ describe a quantity estimate in tons and cubic meters of $C \& D$ waste to be generated on site, which is coded according to the European Waste List published by Order MAM/304/2002 [21]. The estimates are: $15 \%$ humidity pine wood, solid bricks of dimensions $250 \mathrm{~mm} \mathrm{x}$ $125 \mathrm{~mm} \times 62.5 \mathrm{~mm}$ and mass of $3.6 \mathrm{~kg}$, gas at $15^{\circ} \mathrm{C}$. Wastes marked with an asterisk $\left(^{*}\right)$ are considered hazardous waste.

For example, the waste calculation for the volume of concrete, EWL code: 170101 concrete [20], is determined as follows:

From equation (1), $\mathrm{M}_{\mathrm{o}}$ is the waste quantity that is obtained from the original material measurement,

Foundation: $351.60 \mathrm{~m} \times 1.00 \mathrm{~m} \times 1.00 \mathrm{~m}=351.76 \mathrm{~m}^{3}$

Slab: $998.47 \mathrm{~m}^{2} \times 0.15 \mathrm{~m}=149.77 \mathrm{~m}^{3}$

Sports tracks: $(1057.40+801.70) \mathrm{m}^{2} \times 0.15 \mathrm{~m}=278.86 \mathrm{~m}^{3}$

Second slab: $998.47 \mathrm{~m}^{2}$ x $0.30 \mathrm{~m}=299.50 \mathrm{~m}^{3}$

$\mathrm{M}_{\mathrm{o}}=$ Volume in situ $=1079.89 \mathrm{~m}^{3}$

$\mathrm{C}_{\mathrm{r}}$ is 1 because all $\mathrm{M}_{\mathrm{o}}$ is transformed into waste; $\mathrm{C}_{\mathrm{c}}$ is the coefficient to change the constructive element units into waste element units;

Table 3. Non-hazardous Waste Quantities

\begin{tabular}{|c|c|c|c|c|}
\hline EWL Code & Waste Identification (Non-Hazardous) & Density $\mathbf{t} / \mathbf{m}^{3}$ & Volume Inside Trucks $\mathbf{m}^{3}$ & Mass $\mathbf{t}$ \\
\hline 170101 & Concrete & 2.50 & 1349.86 & 2699.72 \\
\hline 170102 & Bricks & 1.84 & 1013.57 & 1459.55 \\
\hline 170201 & Wood & 0.50 & 2.51 & 1.14 \\
\hline 170202 & Glass & 2.50 & 0.67 & 1.60 \\
\hline 170402 & Aluminum & 2.70 & 1.16 & 2.86 \\
\hline 170405 & Iron and steel & 7.85 & 18.82 & 118.22 \\
\hline 170504 & Soil and stones different from 170503 & 1.90 & 787.50 & 1197.00 \\
\hline \multicolumn{4}{|r|}{3174.05} & 5480.03 \\
\hline
\end{tabular}

Table 4. Hazardous Waste Quantities

\begin{tabular}{|c|c|c|c|c|}
\hline EWL Code & Waste Identification (Hazardous) & Density $\mathbf{t} / \mathbf{m}^{3}$ & Volume Inside Trucks $\mathbf{m}^{3}$ & Mass $\mathbf{t}$ \\
\hline $140601 *$ & Chlorofluorocarbons, HCFC, HFC & 0.0036 & 16.60 & 0.06 \\
\hline \multirow[t]{3}{*}{$170902 *$} & Construction and demolition waste containing PCB & 0.58 & 3.73 & 1.96 \\
\hline & & & 20.33 & 2.02 \\
\hline & & TOTAL $=$ & $3194.70 \mathrm{~m}^{3}$ & $5483.89 \mathrm{t}$ \\
\hline
\end{tabular}


$\mathrm{C}_{\mathrm{c}}=$ Density $=2.50 \mathrm{t} / \mathrm{m}^{3}$

and $\mathrm{C}_{\mathrm{T}}$ is the coefficient to transform the measurement criteria from the original constructive element into the measurement criteria for the waste element.

$\mathrm{C}_{\mathrm{T}}=$ Volume inside truck ( $25 \%$ sponged $)=1.25$

$\mathrm{M}=1079.89 \mathrm{~m}^{3} \times 2.50 \mathrm{t} / \mathrm{m}^{3} \times 1.25=2699.72 \mathrm{t}$

\section{Waste Prevention Plan}

The waste prevention plan is a vital aspect for waste management of a more sustainable nature. The prevention plan for the school demolition can be summarized as the following: Selective demolition, Commitment from contractors and personnel, and Periodic work inspections.

Wherever possible, the demolition work is carried out using techniques of selective deconstruction and dismantling in order to encourage the reuse, recycling and recovery of waste. As a general rule, the demolition will begin with the hazardous-waste removal, followed by the separation of recyclable materials, and afterwards, the remaining material to be demolished [22].

Waste prevention plans are to be included in contracts with subcontractors together with a penalty clause which will discourage waste generation due to poor management. In order to reduce waste generation, all personnel involved in the work must have minimum knowledge of waste prevention and proper waste management. Project changes are made, where feasible, to encourage land clearing or reuse [5].

Table 5. Waste to be Reused
There will be a periodic inspection plan of products and waste collected in order to ensure that they are properly maintained. The material is picked up in an orderly manner, thereby preventing damage or waste mixing.

\section{Reuse, Recovery and Disposal Plans}

In the following tables, the destination of the waste is established. Table $\mathbf{5}$ describes the waste to be reused. Table $\mathbf{6}$ lists waste to be reused. Table 7 describes the residues to be the deposit in a landfill. Finally, Table 8 describes the hazardous waste to be picked up by an authorized handler.

\section{Waste Separation Action Plan}

The following actions are taken in order to achieve good waste management during the school demolition. The actions facilitate reuse, recycling and recovery and ensure the hygiene and safety required by article 5.4 of the RD 105/2008 [4]:

"Article 5.4: The waste holder must, while remaining under his/her control, keep C\&D waste in proper hygienic and safe conditions and prevent mixing previously separated fractions, in such a way that does not limit its subsequent recovery or disposal".

First, all work areas intended for waste storage are conveniently signposted for each waste type. Second, all packaging waste must be clearly identified, indicating the name, EWL code, holder name, and address and specific risks.

\begin{tabular}{|c|c|c|c|c|}
\hline EWL Code & Waste Identification & Density $t / \mathbf{m}^{3}$ & Volume Inside Trucks $\mathrm{m}^{3}$ & Mass t \\
\hline 170504 & $\begin{array}{c}\text { Land and stones other than those specified in code } 170503 \\
\text { Adjacent landfill (50\% soil generated) }\end{array}$ & 1.90 & 393.75 & 598.50 \\
\hline & & Total Reused = & $393.75 \mathrm{~m}^{3}$ & $598.50 \mathrm{t}$ \\
\hline
\end{tabular}

Table 6. Waste to be the Reused

\begin{tabular}{|c|c|c|c|c|}
\hline EWL Code & Waste Identification & Density $t / \mathrm{m}^{3}$ & Volume Inside Trucks $\mathbf{m}^{3}$ & Mass t \\
\hline 170101 & $\begin{array}{l}\text { Concrete } \\
\text { Destination: Construction site ( } 80 \% \text { volume generated). }\end{array}$ & 2.50 & 1079.89 & 2159.77 \\
\hline 170101 & $\begin{array}{l}\text { Concrete } \\
\text { Destination: Treatment plant ( } 20 \% \text { volume generated) }\end{array}$ & 2.50 & 269.97 & 539.95 \\
\hline 170102 & $\begin{array}{l}\text { Bricks } \\
\text { Destination: Construction site ( } 80 \% \text { volume generated). }\end{array}$ & 1.84 & 810.85 & 1167.64 \\
\hline 170102 & $\begin{array}{l}\text { Bricks } \\
\text { Destination: Treatment plant (20\% volume generated) }\end{array}$ & 1.84 & 202.72 & 291.91 \\
\hline 170201 & $\begin{array}{l}\text { Wood } \\
\text { Destination: Recycling plant }\end{array}$ & 0.50 & 2.51 & 1.14 \\
\hline 170202 & $\begin{array}{l}\text { Glass } \\
\text { Destination: Recycling plant }\end{array}$ & 2.50 & 0.67 & 1.60 \\
\hline 170402 & $\begin{array}{l}\text { Aluminum } \\
\text { Destination: Recycling plant }\end{array}$ & 2.70 & 1.16 & 2.86 \\
\hline 170405 & $\begin{array}{l}\text { Iron and steel } \\
\text { Destination: Recycling plant }\end{array}$ & 7.85 & 18.82 & 118.22 \\
\hline \multicolumn{3}{|c|}{ TOTAL RECOVERED = } & $2386.60 \mathrm{~m}^{3}$ & $4283.10 t$ \\
\hline
\end{tabular}


Table 7. Non-hazardous Waste to be the Deposit in a Landfill

\begin{tabular}{|c|c|c|c|c|}
\hline EWL Code & Waste Identification & Density $\mathbf{t} / \mathbf{m}^{3}$ & Volume Inside Trucks $\mathbf{m}^{3}$ & Mass t \\
\hline 170504 & $\begin{array}{l}\text { Land and stones other than those specified in the code } 170503 \\
\text { Destination: Landfill ( } 50 \% \text { soil generated). }\end{array}$ & 1.90 & 393.75 & 598.50 \\
\hline \multicolumn{3}{|c|}{ Total Deposit = } & $393.75 \mathrm{~m}^{3}$ & $598.50 \mathrm{t}$ \\
\hline
\end{tabular}

Table 8. Hazardous Waste Which Needs to be Picked up by an Authorized Hazardous-waste Handler

\begin{tabular}{|c|c|c|c|c|}
\hline EWL Code & Waste Identification & Density $t / \mathrm{m}^{3}$ & Volume Inside Trucks $\mathrm{m}^{3}$ & Mass $\mathbf{t}$ \\
\hline $140601^{*}$ & $\begin{array}{l}\text { Chlorofluorocarbons, HCFC, HFC } \\
\text { Destination: Hazardous waste authorized manager }\end{array}$ & 0.0036 & 16.60 & 0.06 \\
\hline $170902 *$ & $\begin{array}{l}\text { Construction and demolition waste containing PCB } \\
\text { Destination: Hazardous waste authorized manager }\end{array}$ & 0.58 & 3.73 & 1.96 \\
\hline \multicolumn{3}{|c|}{ TOTAL MANAGED = } & $20.33 \mathrm{~m}^{3}$ & $2.02 \mathrm{t}$ \\
\hline
\end{tabular}

Hazardous waste is deposited in reservoirs of an appropriate size and protected from the rain. Hazardouswaste storage areas must be sufficiently separated from nonhazardous, thereby preventing contamination of the latter.

Waste is deposited in its corresponding place as it is generated. Waste will be stored in containers, suitable in number and volume, and any overloading of containers is to be avoided. Containers which are close to public access need to be protected outside work hours with canvas or similar in order to avoid uncontrollable spills by third parties that may cause waste mixing or contamination.

The quantity of waste from the school demolition lies within the limits as established in Article 5.5 of the decree, but separation takes place all the same.

\section{Graphical Documentation}

The selection of the location where the management of C\&D waste (crushing and separation) could take place (onsite or off-site) is based on the following parameters [22]:

- Availability of machines.

- Required quality of recyclable materials in order to be used at the worksite.

- On-site space availability.

- Distance between the worksite and the nearest recycling center or landfill.

Graphical documentation attached contains: a zone for non-hazardous waste separation and storage, a zone for hazardous waste separation and storage, a zone for a mobile recovery plant installation, and a zone for reused waste storage, see Fig. (4).

\section{Technical Instructions}

The technical instructions covering the school demolition are now described. First, it is necessary to fix and secure potentially hazardous items on the construction site and the surrounding buildings. As a general rule, the removal of pollutants and/or hazardous items takes place first, as well as the deconstruction of valuable elements (ceramics, marble......). Second, the deconstruction of accessible parts of installations, carpentry and other elements takes place. Finally, the demolition is performed.

The temporary storage of the debris is provided by industrial sacks of a maximum of 1 cubic meter, and specific containers are located and conditions are established by municipal by laws. Such containers must also be tagged and segregated in an appropriate way.

The construction site manager must take any necessary action to prevent the deposit of foreign waste. Containers will remain closed or covered, at least outside work hours. The technical team of the construction site will establish the human, technical and separation resources for each C\&D waste type.

The contractor performs an economic assessment of the conditions in which this operation is feasible, and takes into account appropriate handlers/recycling plant availability. The construction site management is responsible for the final decision taken and its justification to local and regional authorities.

The final destination of the waste must be an authorized company (recycling plant, landfill, quarry, incineration plant, plastic/wood recycling plant), and be registered in the corresponding agency. Transportation must also be performed by authorized and registered enterprises. For the C\&D waste reused in other construction sites (soil, stones...) or quarry restoration, the project manager must provide documentary evidence of its final destination.

The hazardous waste management during demolition work must meet national legislation, regional legislation and the local bylaw requirements. Furthermore, any generated urban waste, such as food leftovers, packaging, sewerage, mud and sludge) must be managed in compliance with municipal bylaws. The rinsing water from a concrete mixer, after solidification, can be treated as non-hazardous waste. Contamination of plastic and wood by toxic or hazardous products must be prevented. 


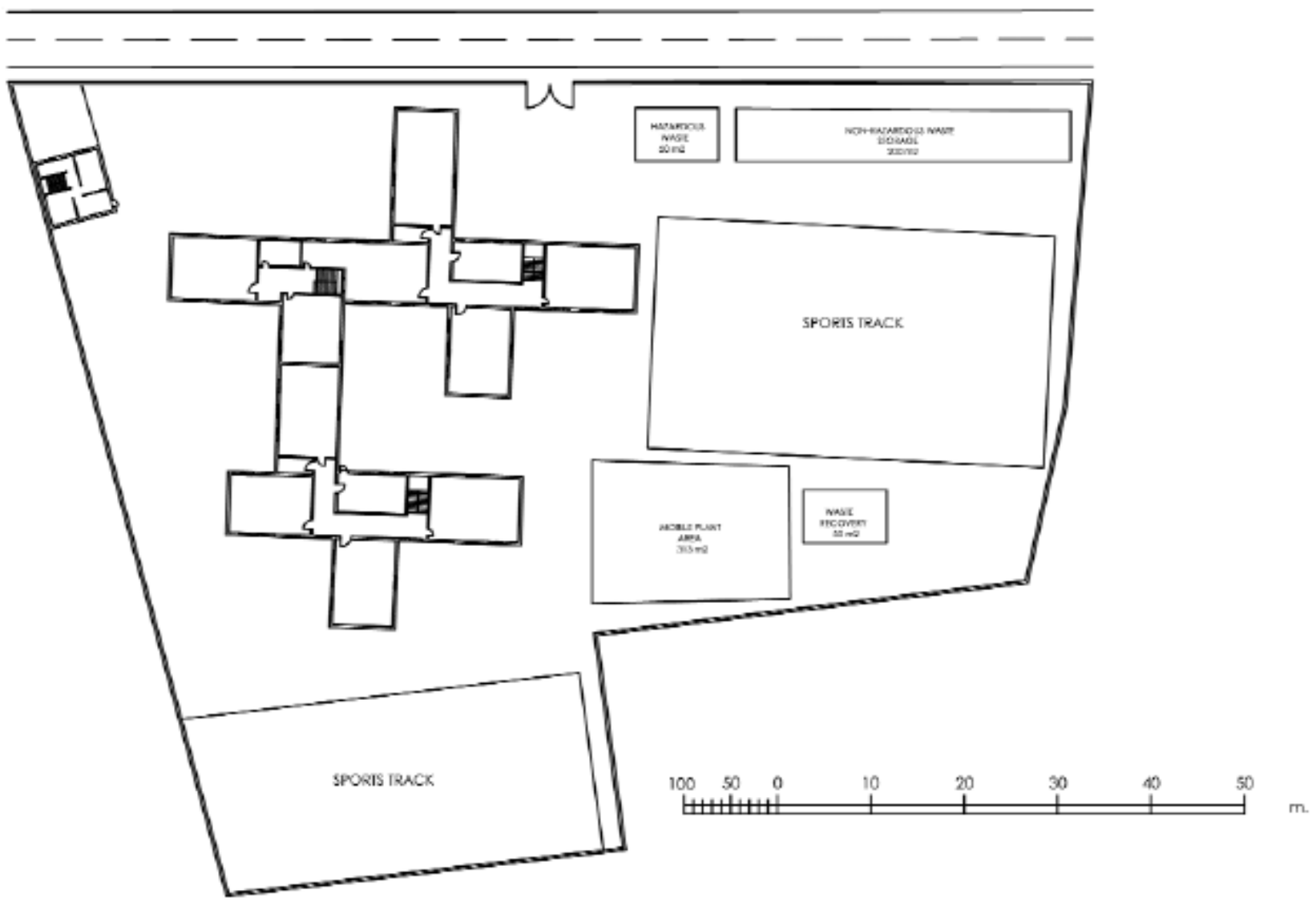

Fig. (4). The space needed for the $C \& D$ waste management: separation and in-situ treatment.

Surface soil, to be used for gardening or refills, must be removed and stored during the shortest possible time in mounds of a maximum of 2 metres high, thereby preventing excessive moisture and contamination with other materials. Detection of potentially contaminated soil must be reported to authorities, in accordance with national and regional legislation.

\section{Budget}

In Table 9, the C\&D waste management budget is described.

\section{CONCLUSIONS}

The application of the RD 105/2008 requires, not only meeting the established requirements, but also changing a trend that has been in place for years regarding the management of $C \& D$ waste. The legislation takes a major step towards waste prevention, and where this is infeasible, towards sustainable recovery. The trend of the construction sector however, has always been to consider all waste as inert whereby it ends up in landfills or, in many cases, in uncontrolled dumps.

The current regulatory framework requires companies to manage their own waste, either by taking waste management measures compatible with the activity of the company, or by hiring services from a waste management company. It is therefore necessary to change $\mathrm{C} \& \mathrm{D}$ waste management in order to meet both regulations and the growing social concerns which demand a clear commitment to waste prevention, reuse and recycling from the construction industry. Market development and promotion for "new products" are needed in order to render recovery and recycling as valid activities.

In addition to the need to create new markets, our construction sector presents a unique set of barriers, such as: its nomadic character, unique designs, materials with long lifecycles, the necessity to measure something which does not exist (waste to be avoided). The most obvious is the nomadic nature of the work. In other words, the work moves to where it is carried out and adapts to the environment that surrounds it, with all the disadvantages which this entails. These characteristics significantly influence the choice of preventive actions, as well as its effectiveness.

The unique design: Construction activities are often unique and unrepeatable. Building demolition is not an industrial process that "produces" products subject to repetitive specifications; each project corresponds to an elaborate and unrepeatable design. It can be argued that individual units of work are often repetitive with respect to materials, products and their characteristics. Even in the event that work units are apparently similar, often materials and products undergo treatment that causes different environmental impacts. To this end, prevention action plans must be incorporated into planned and projected construction activities.

Materials with a long lifecycle: The C\&D waste generated during a demolition today comes from products 
Table 9. The Demolition Waste Management Budget is Organized Using Andalusia's WBS

\begin{tabular}{|c|c|c|c|c|c|}
\hline \multicolumn{6}{|l|}{ Budget } \\
\hline Code & $U$ & Description & Quantity & Cost & Total \\
\hline \multirow[t]{2}{*}{ 17АНА00220 } & $\mathrm{T}$ & $\begin{array}{l}\text { STEEL WASTE DISPOSAL. } \\
\text { MAX. DISTANCE } 15 \mathrm{~km}\end{array}$ & 118.22 & -65.88 & -7788.33 \\
\hline & & \multicolumn{4}{|c|}{$\begin{array}{l}\text { Waste transported in a truck up to } 15 \mathrm{~km} \text { away. Includes loading, transport, unloading and treatment fee. Weighed on a scale } \\
\text { and left in the treatment plant. }\end{array}$} \\
\hline \multirow[t]{2}{*}{ 17MMM00120 } & $\mathrm{T}$ & $\begin{array}{l}\text { WOOD WASTE DISPOSAL. } \\
\text { MAX. DISTANCE } 15 \mathrm{~km}\end{array}$ & 1.14 & 14.16 & 16.14 \\
\hline & & \multicolumn{4}{|c|}{$\begin{array}{l}\text { Waste transported in a truck up to } 15 \mathrm{~km} \text { away. Includes loading, transport, unloading and treatment fee. Weighed on a scale } \\
\text { and left in the treatment plant. }\end{array}$} \\
\hline \multirow[t]{2}{*}{ 17ТTT00120 } & $\mathrm{m} 3$ & $\begin{array}{l}\text { SOIL WASTE DISPOSAL. } \\
\text { MAX. DISTANCE } 15 \mathrm{~km}\end{array}$ & 393.75 & 9.16 & 3606.75 \\
\hline & & \multicolumn{4}{|c|}{$\begin{array}{l}\text { Soil transported in a truck up to } 15 \mathrm{~km} \text { away. Includes separation, loading, transport, unloading and treatment fee. Measured } \\
\text { in sponged volume. }\end{array}$} \\
\hline \multirow[t]{2}{*}{ 17ТTT00300 } & $\mathrm{m} 3$ & $\begin{array}{l}\text { SOIL WASTE SENT TO ANOTHER CONST. SITE. MAX. } \\
\text { DISTANCE } 5 \mathrm{~km}\end{array}$ & 393.75 & 3.04 & 1197.00 \\
\hline & & \multicolumn{4}{|c|}{$\begin{array}{l}\text { Soil transported in a truck to another construction site } 5 \mathrm{~km} \text { away. Includes loading, transport, unloading and treatment fee. } \\
\text { Measured in sponged volume. }\end{array}$} \\
\hline \multirow[t]{2}{*}{ 17HAW00320 } & $\mathrm{m} 3$ & $\begin{array}{l}\text { AGGREGATE AND STONE WASTE DISPOSAL. MAX. } \\
\text { DISTANCE } 15 \mathrm{~km}\end{array}$ & 472.69 & 17.16 & 8111.36 \\
\hline & & \multicolumn{4}{|c|}{$\begin{array}{l}\text { Waste transported in a truck up to } 15 \mathrm{~km} \text { away. Includes loading, transport, unloading and treatment fee. Measured in } \\
\text { sponged volume. }\end{array}$} \\
\hline \multirow[t]{2}{*}{ 17AAA00100 } & $\mathrm{T}$ & $\begin{array}{l}\text { ALUMINUM WASTE DISPOSAL, RECYCLING PLANT. } \\
\text { MAX. DISTANCE } 15 \mathrm{~km}\end{array}$ & 2.86 & -70.88 & -202.72 \\
\hline & & \multicolumn{4}{|c|}{$\begin{array}{l}\text { Waste transported in a truck up to } 15 \mathrm{~km} \text { away. Includes loading, transport, unloading and treatment fee. Weighed on a scale } \\
\text { and left in the recycling plant. }\end{array}$} \\
\hline \multirow[t]{2}{*}{ 17MMV00100 } & $\mathrm{T}$ & $\begin{array}{l}\text { GLASS WASTE DISPOSAL. } \\
\text { MAX. DISTANCE } 15 \mathrm{~km}\end{array}$ & 1.60 & 8.16 & 13.06 \\
\hline & & \multicolumn{4}{|c|}{$\begin{array}{l}\text { Waste transported in a truck up to } 15 \mathrm{~km} \text { away. Includes loading, transport, unloading and treatment fee. Weighed on a scale } \\
\text { and left in the recycling plant. }\end{array}$} \\
\hline \multirow[t]{2}{*}{ 17WWH00100 } & $\mathrm{m} 3$ & $\begin{array}{l}\text { WASTE CONTAINING HCFC AUTHORIZED HANDLER. } \\
\text { MAX. DISTANCE } 15 \mathrm{~km}\end{array}$ & 16.60 & 92.29 & 1532.01 \\
\hline & & \multicolumn{4}{|c|}{$\begin{array}{l}\text { Waste disposal containing chlorofluorocarbons by authorized agent located at a maximum distance of } 15 \mathrm{~km} \text {. Includes: } \\
\text { loading, transportation, unloading and management fee. Volume measured in a gaseous state at } 15^{\circ} \mathrm{C} \text {. }\end{array}$} \\
\hline \multirow[t]{2}{*}{ 17WWP00100 } & $\mathrm{T}$ & $\begin{array}{l}\text { WASTE CONTAINING PCB AUTHORIZED HANDLER. } \\
\text { MAX. DISTANCE } 15 \mathrm{~km}\end{array}$ & 1.96 & & 0.00 \\
\hline & & \multicolumn{4}{|c|}{$\begin{array}{l}\text { Waste disposal containing PCB by authorized agent located at a maximum distance of } 15 \mathrm{~km} \text {. Includes: loading, } \\
\text { transportation, unloading and management fee. Weighed on a scale and left in the recycling plant. }\end{array}$} \\
\hline \multirow[t]{3}{*}{ 17HAW00400 } & $\mathrm{T}$ & WASTE TREATED IN SITU FOR REUSE. & 3327.41 & 1.82 & 6055.89 \\
\hline & & \multicolumn{4}{|c|}{ Aggregate and stone waste treated on site using a mobile plant. Includes material loading. Measured weight. } \\
\hline & & & 1.00 & 12541.16 & 12541.16 \\
\hline
\end{tabular}

that were designed, manufactured, and laid many years ago. In turn, building products that are designed, manufactured, and laid today will become waste many years ahead, and hence many of the waste prevention actions which take place today, will render a payback in the distant future. 
A measure "that which does not exist": In the prevention of C\&D waste it is necessary to measure "that which does not exist", i.e. the waste whose generation is to be prevented. This implies a greater drawback to motivation for waste prevention, thereby making it necessary not only to promote public initiatives but also to provide public aid, with a particular focus on prioritizing those project innovations which encourage $C \& D$ waste prevention by developers and constructors, as well as by manufacturers of construction products.

\section{ACKNOWLEDGEMENT}

None declared.

\section{CONFLICT OF INTEREST}

None declared.

\section{REFERENCES}

[1] Plan Nacional Integrado de Residuos (PNIR) 2007-2015 "National Integrated Waste Plan 2007-2015", Madrid: Ministry of the Environment, 2007.

[2] P. Agamuthu, "Challenges in sustainable management of construction and demolition waste", Waste Manag. Res., vol. 26, no. 6, pp. 491-492, 2008.

[3] Plan Nacional de Residuos de Construcción y Demolición 20012006 "National C\&D Waste Plan 2001-2006", Madrid: Ministry of the Environment, 2001.

[4] Real Decreto $105 / 2008$, de 1 de febrero, por el que se Regula la Producción y Gestión de los Residuos de Construcción y Demolición (Royal Decree 105/2008, February 1, which Regulates the Production and Management of Construction and Demolition Waste), Madrid: Ministry of the Presidency, 2008.

[5] Code for Sustainable Homes, London: Department for Communities and Local Government, 2006.

[6] G. Rodríguez, J.A. Francisco, and M. Germán, "The contribution of environmental management systems to the management of construction and demolition waste: The case of the Autonomous Community of Madrid (Spain)", Resour Conserv Recycling, vol. 50, pp. 334-349, 2007.

[7] M. del Río, P. Izquierdo, and I. Salto Weis, "Sustainable construction: construction and demolition waste reconsidered", Waste Manag. Res., vol. 28, pp. 118-129, 2010.

[8] Consejería de Obras Públicas y Vivienda de la Junta de Andalucía "Base de Costes de la Construcción de Andalucía 2008 (Andalusian Construction Cost Database 2008)", 2008. [Online] Available: http://www.juntadeandalucia.es/obraspublicasyvivienda/ portal-web/web/areas/vivienda/texto/bcfbb3af-ee3a-11df-b3d321796ae5a548 [Accessed: Nov. 15, 2010].
[9] J. Solis-Guzman, M. Marrero, M.V. Montes-Delgado, and A. Ramirez-de-Arellano, "A Spanish model for quantification and management of construction waste", Waste Manag., vol. 29, pp. 2542-2548, 2009.

[10] Ordenanza Marco de Residuos de la Construcción y Demolición de la Mancomunidad de los Alcores (Draft by law of the Community of Los Alcores C\&D Waste), Seville: Local Authorities of the Los Alcores Community, 2003.

[11] Manual de directrices para el uso de áridos reciclados en obras públicas de la Comunidad Autónoma del País Vasco, País Vasco: Gobierno Vasco, 2009.

[12] SuperDrecksKescht fir Betriber. Oeko-Service Luxembourg. Abfallmanagement im Hochbau mit der Zielvorgabe Abfallvermeidung. LIFE97 ENV/L/000206. Internet Version 31.07.2002 Luxenbourg. http://www.superdreckskescht.lu [Online] Available: http://www.omniclass.org [Accessed: November 6, 2009].

[13] Instituto de Tecnologia de la Construccion de Cataluna, ITEC (Catalonia Institute of Construction Technology). Catalonia, Spain, 2000. [Online] Available: http://www.itec.es/nouBedec.e/ presentaciobedec. aspx [Accessed: November 6, 2009].

[14] SMARTWaste ${ }^{\mathrm{TM}}$, Building Research Establishment (BRE) Ltd, Watford, United Kingdom, 2008. [Online] Available; http://www.smartwaste.co.uk [Accessed: November 6, 2009].

[15] M. Marrero, and A. Ramirez-de-Arellano, "The building cost system in Andalusia: application to construction and demolition waste management”, Constr. Manag. Econ., vol. 28, pp. 495-507, 2010.

[16] Construction Specifications Institute/Construction Specifications Canada (CSI/CSC), Masterformat Manual of Practice (MP2-1), Alexandria; 2004.

[17] Omniclass (2006) Omniclass construction classification system, Edition 1.0, Construction Specifications Institute (CSI), [Online] Available; http://www.omniclass.org [Accessed: November 6,2009].

[18] Uniclass-unified classification for the construction industry, London: National Building Specification Service Ltd., 1996.

[19] The Institute of Civil Engineering. Civil Engineering Standard Method of Measurement. Thomas Telford LTD, United Kingdom 1991.

[20] European Waste List (EWL). Adopted by Decision 2000/532/EC, last amended by Council Decision 2001/573/EC, 2000.

[21] Orden MAM/304/2002, de 8 de febrero, por la que se publican las operaciones de valorización y eliminación de residuos y la lista europea de residuos (National Decree MAM/304/2002 which publishes the waste recovery and elimination operations and the European Waste List), Madrid: Ministry of the Environment, 2002.

[22] B. Kourmpanis, A. Papadopoulos, K. Moustakas, M. Stylianou, K.J. Haralambous, and M. Loizidou, "Preliminary study for the management of construction and demolition waste", Waste Manag. Res., vol. 26, pp. 267-275, 2008.

(C) Marrero et al.; Licensee Bentham Open.

This is an open access article licensed under the terms of the Creative Commons Attribution Non-Commercial License (http://creativecommons.org/licenses/by-nc/3.0/) which permits unrestricted, non-commercial use, distribution and reproduction in any medium, provided the work is properly cited. 